\title{
The Quality Of Audit Results In Public Sector
}

\author{
Rida Perwita Sari and Sari ${ }^{1}$, Sri Hastuti and Hastuti ${ }^{2}$, Dyah Ratnawati and Ratnawati ${ }^{3}$, \\ Munari and Munari ${ }^{4}$, Rika Puspita Sari and Sari ${ }^{5}$ \\ \{ridaps.ak@upnjatim.ac.id ${ }^{1}$, tutik.hastuti18@gmail.com², dratnawati67@gmail.com³, \\ munari.ak@upnjatim.ac.id ${ }^{4}$, rika.puspita07@gmail.com ${ }^{5}$ \}
}

University of Pembangunan Nasional Veteran Jawa Timur, Surabaya, Indonesia ${ }^{1,2,3,4}$, Universitas Dr Soetomo, Surabaya, Indonesia ${ }^{5}$

\begin{abstract}
The purpose of this study is to examine competence, Independence, Compliance Pressure, Internal Control Systems and Organizational Commitment to the Quality of Audit Results with theInternal Audit Capability Model (IACM) approach using agency theory, Theory of Attitudes and Behavior and attribution theory. The subject of this research is Internal Audit in Indonesia. This research uses proportional random sampling technique. Samples used as much as 108 auditors. The analysis technique used in this study is Partial Least Square (PLS) with the help of warpPLS software. The results showed that competency, independence and organizational commitment affect the Quality of Audit Results, while compliance pressure and internal control systems do not affect the quality of audit results. This research uses the Internal Audit Capability Model (IACM) approach which is a new framework that illustrates the basic things needed to realize effective internal public sector auditor
\end{abstract}

Keywords: Internal Audit Capability Model (IACM), Competence, Independence, Compliance Pressure, Internal Control Systems, Organizational Commitment, Quality of Audit Results

\section{Introduction}

All this time, the public sector has not escaped the accusation as a hotbed of corruption, collusion, nepotism, inefficiency and a source of state waste. The government as one of the public sector organizations also do not escape this accusation. Government public sector organizations are institutions which run the wheels of government whose source of legitimacy comes from the public. Therefore, the trust given by the public to government administrators must be balanced with a clean government. The public demands a clean government administration with a better and tighter internal control system. The role of government in eradicating corruption varies greatly between public services, between people, between national government systems, and between the amount of corruption itself. The demand for implementing public sector accountability towards the realization of good governance in Indonesia is increasing. This demand is reasonable, because several studies have shown that 
the economic crisis in Indonesia was caused by poor management (bad governance) and bad bureaucracy (Rose et al, 2019).

Government Auditing Standards (2011) explained the concept of accountability for the use of public resources and government authority is the key to the process of managing a nation. Management and officials who have authority over public resources are responsible for carrying out public service functions and providing services to the public effectively, efficiently, economically, ethically, and fairly. The need for accountability has led to requests for more information about government programs and services.

Public officials, legislators, and citizens want and need to know whether government funds are handled properly and in accordance with laws and regulations. They also want and need to know whether government organizations, programs and services achieve their goals and whether organizations, programs and services operate economically and efficiently. Internal monitoring conducted by (APIP) contained in Government Internal Control System (SPIP) consists of an audit, review, evaluation, monitoring and other monitoring activities. Supervision serves to help the goals set by the organization can be achieved, in addition to supervision to detect early detection of implementation deviation, abuse of authority, waste and leakage (Sukriah, et al. 2009). The regional inspectorate must organize the general supervision activities of the local government and other tasks assigned by the regional head so that in his duties the inspectorate is the same as the internal auditor (Falah, 2005).

Internal audits are audits conducted by inspection units that are part of a supervised organization (Mardiasmo, 2005). Examination conducted APIP sometimes encountered obstacles in the implementation where the sense of kinship, togetherness and humane considerations stand out. Another problem faced in improving the quality of APIP is how to improve the attitude or behavior, the ability of the supervisory apparatus in conducting the examination, so that the supervision can run fairly, effectively and efficiently (Sukriah, et al. 2009).

APIP wants a clean, authoritative, orderly, and orderly supervisory body in carrying out its duties and functions by prevailing rules and norms. The norms and conditions applicable to internal auditors government consist of the Code of Conduct of APIP and APIP Audit Standards. Code of ethics is intended to maintain the behavior of APIP in carrying out its duties, while the Audit Standard is intended to maintain the quality of audit conducted by APIP. Given these rules, the public or users of the report can assess the extent to which government auditors have worked by predetermined standards and ethics.

Knechel, Krishnan, Pevzner, Shefchik, and Velury (2012) say that audit quality is often debatable but little understood. It has been more than 20 years since the research on the quality of the audit, but not much agreement has been reached on how to define quality but gives each party a better understanding of audit quality. Thus a "good" audit is a well-executed audit based on proper audit process planning by a trained and trained auditor who understands the uncertainty of the audit process and can sense the unique circumstances of the auditee.

The phenomenon that occurs is the quality of audits conducted by auditors Inspectorate apparatus is still a public concern. This is because the audit findings are not detected by the Inspectorate apparatus as an internal auditor. However, found by the Supreme Audit Agency (BPK) as an external auditor, this indicates that the audit quality of the Inspectorate apparatus is still relatively poor. It is supported by a report from the Association of Indonesian Government Internal Auditors (AAIPI) which states that 94 percent of Government Internal 
Supervisory Officers (APIP) in central and regional levels cannot detect corruption. This is one of the results of mapping data of Government Internal Supervisory Apparatus (APIP) based on Internal Audit Capability Model (IACM) approach to 331 APIP. Of the five levels in the IACM approach, 93.96 percent of supervisors are at level only 5.74 percent in the second level while only one APIP is at level III. Level one cannot detect corruption. This ability is owned after level II upwards. This is very alarming given the government's internal supervisory function that is the vanguard for the prevention and eradication of corruption. (source: http://www.suarapembaruan.com/home/94-persen-auditor-pemerintah-tak-bisadeteksi-korupsi/28413). The same thing happened during this time found many cases of irregularities in the field indicated corruption, which escaped from the supervision Inspectorate. Many underlying factors, such as discipline, are also mental issues. (source: (sumber: https://petajatim.id/lemahnya-pengawasan-inspektorat-daerah-memicu-banyakpertanyaan/).

The Regional Inspectorate in carrying out its main tasks and functions in the field of supervision / audit, should have been able to assess the efficiency, effectiveness, economical (3E) in conducting an audit of an activity and able to provide consultation on governance, risk management, and internal control so that accountability will manifest public compliance with applicable laws and regulations. Wibowo (2010) argued that the implementation of supervisory tasks undertaken by APIP is strongly influenced by two factors: internal factors and external factors. Faizah and Zuhdi (2013) put forward efforts to obtain quality examination results, an auditor in carrying out its supervisory task is strongly influenced by the characteristics of each of the auditor's personnel.

Characteristics of an auditor derived from internal factors (dispositional attributions ) that refers to the behavior of individuals that exist within a person, and external factors ( situational attributions ) refers to the surrounding environment that affects the behavior of someone who encourages a person (auditor) to act. This is in line with the statement of Zulfahmi (2005) which suggests that the factors that influence one's behavior include: (1) internal factors (personal), factors that come from within the individual, (2) external factors (situational) comes from outside the human self that can lead to a person tend to behave according to the characteristics of the group or organization in which he participated in it.

According to Salsabila and Prayudiawan (2011) the quality of auditors work is strongly influenced by individual characteristics of each accountant. Individual characteristics are one of them is the gender that has distinguished the individual as the basic nature of human nature. The existence of gender inequality is caused by structural and institutional discrimination. The composition of male and female auditors is very much different. Although the competencies required for this profession have nothing to do with gender, according to the facts and data available, the existence of women in this profession is very minimal. In contrast to the results of Kris et al. (2011) research that in generating audit reporting, differences (women and men) can affect audit quality. One of the reasons is that female auditors are better and experienced in handling conflict than male auditors. Kusumayanti et al., (2014) mentions that women are suspected to be more efficient and effective in processing information when there is a complexity of tasks in decision making than men.

This study will examine the internal factors of competence and independence, and the external factor is the pressure of obedience that affects the quality of audit results generated by government auditors (APIP). In addition to the personal characteristics of an auditor derived 
from internal factors, as a determinant of the quality of the results of the examination is very influenced also by external factors (situational). External factors (situational) in this case is the pressure (pressure) that comes from the boss or audite (client) is audited. The pressure of obedience arises from the existence of the command given by the individual who is in the position of authority.

This study explores novelty in addition to the research time aspect; this study will examine the influence of internal and external factors simultaneously, besides this research will use bigger sample by using different analytical tool that is using Partial Least Square (PLS) with WarpPLS program. The usual pressure on the government environment is more focused on obedience pressure because government auditors work on the orders for and on behalf of APIP as an institution under the control or authorization. This study is an interesting study because it not only examines the internal factors of an auditor but also wants to see how far the external factors, in this case, the pressure of obedience in the work environment of APIP (Inspectorate) can affect the quality of audit results based on internal audit capability model (IACM).

The contribution of the results of this study is expected to provide theoretical benefits, especially in the field of Public Sector Accounting for further studies, especially in the field of audit as a form of adoption of agency theory and attribution theory. Both theories are related to adverse selection and moral hazard, as well as dispositional attributions and situational attributions. Practical benefits are expected to be used as input materials for APIP institutions as internal stakeholders to always use and improve the expertise of the auditor by taking into account the competence of the auditors in APIP institutions and internal controls in it to obtain the results of the audit quality result.

The policy benefit is expected to give input to Local Government in East Java Province to make policy in the field of supervision especially about placement and assignment of personnel (auditor) at APIP institution by considering competence that is knowledge / educational background, as PERMENPAN No: PER/05/M.PAN/03/2008 on educational background, APIP Auditors, have a minimum level of formal education (S-1) or equivalent, and also consider the expertise and experience of personnel to be placed at APIP (Inspectorate). The research objectives to be achieved in this study to determine the effect of competence, Independence and Pressure of Obedience to Audit Quality Based on Audit Capability Model (IACM).

Based on agency theory, Jensen and Meckling (1976) argue that agency relationships can occur in all entities that rely on contracts, either explicitly or implicitly, as a reference to participant behavioral behavior. Therefore it can be said that an agency relationship occurs in every entity. The application of agency theory to public sector organizations can be realized in work contracts that regulate the proportion of the rights and obligations of each party while taking into account the overall benefit (Arifah, 2012).

Public sector organizations through local government, especially APIP (Inspectorate) institutions as internal stakeholders always strive to increase public trust (community) and auditee as external stakeholders through the implementation of quality internal supervision function, to realize clean, fair, transparent and accountable administration. Implementation of internal oversight function implemented by APIP as an institution that performs duty and responsible to a regional leader, in this relation is as principal delegate authority to the auditor to perform inspection task to local governance. As a result, auditors who act as agents have access to more information and authority in the audit process. The imbalance (asymmetry) of 
information held between the internal auditor and the government represented by the supervisory body (APIP) in the conduct of the audit can cause problems.

Attribution theory there are behaviors that relate to the attitudes and characteristics of individuals, in other words, see the behavior will be known attitudes or characteristics of the person and can also predict the behavior of a person in the face of certain situations. A person will form ideas about other people, and situations in the surrounding environment that cause a person's behavior in social perception is called the dispositional attributions and situational attribution on. Dispositional attribution refers to the individual behavior that exists within a person (internal factors) such as competence, and independence possessed by an auditor, and the site attributions refer to the surrounding environment that affects behavior (external factors) such as pressure and rules (in this case the application SPI).

Robbins (2006) stresses that attribution theory deals with the cognitive process in which an individual interprets a person's behavior about a particular part of the relevant environment. Attribution theory which is characteristic of attribution theory explains that humans are rational and are encouraged to identify and understand the structural causes of their environments. It explains that the behavior is related to the attitude and characteristics of the individual, so that attitudes and characteristics can deal with situations in certain environments such as when conducting surveillance and inspection in government institutions, so that APIP behavior in acting should be in accordance with the ability, rules, and rules of relevant procedures in the environment.

The Government Accountability Office (GAO) defines audit quality as adherence to professional standards and contractual ties during audits (Lowenshon et al., 2005). Auditing standards serve as guidance and measures of auditor performance quality (Messier et al., 2005). According to the Regulation of the State Minister for Administrative Reforms PER / 05 / M.PAN / 03/2008, the quality of audit on financial statements, done by APIP shall use State Auditing Standards (SPKN). State Audit Standards (SPKN) that the conduct of inspections based on inspection standards will increase the credibility of reported information (obtained) from entities examined through the collection and testing of evidence objectively. The quality elements of the inspection report must be timely, complete, accurate, objective, convincing, and clear, and as concise as possible. Therefore, the quality of the examination result is the quality of the auditor's work which is indicated by a reliable result report.

Internal Audit The Government or better known as the Government Internal Supervisory Apparatus (APIP) performs functional oversight of state finance management to be efficient and effective to assist government management in the framework of control over the activities of its work unit ( quality assurance function ). The contribution of APIP is expected to give input to the leaders of the government regarding the outcomes, obstacles, and deviations that occur on the course of government and development which is the responsibility of the leaders of the government organizers. Institutions/bodies/units within the government body (Internal Government Controller), which has the duty and function of functional oversight is APIP, which consists of: The Financial and Development Supervisory Board (BPKP) Inspectorate General Department Main Inspectorate/Inspectorate of Non Departmental Government Institution (LPND)/Ministry Regional Supervisory Agency or Provincial / Regency / City Bawasda.

Based on the Regulation of the Republic of Indonesia Financial Examination Agency Number 01 of 2007 concerning State Auditing Standards. The first general standard statement of the SPKN is: "Collectors must collectively have sufficient professional skills to carry out 
the inspection task". This Statement of Inspection Standards is that all inspection organizations are responsible for ensuring that each inspection is carried out by examiners who collectively have the knowledge, expertise and experience needed to carry out these tasks. Therefore, the examining organization must have recruitment, appointment, continuous development and evaluation procedures for examiners to assist the examining organization in maintaining examiners who have adequate competence.

Auditor independence is needed because the auditor is often referred to as the first party and plays a major role in conducting performance audits, because the auditor can access financial and management information from the organization being audited, has professional capabilities and is independent. Despite the fact that this independent principle is difficult to truly implement absolutely, between the auditor and the auditee must strive to maintain such independence so that the audit objectives can be achieved. Mulyadi (2005) defines independence as "a state free from influence, not controlled by other parties, not dependent on others" and an independent public accountant must be a public accountant who is not affected and is not influenced by various forces that come from outside the accountant's self in considering the facts that he found in the examination. Arens, et.al (2000) defines independence in auditing as "The use of an unbiased perspective in carrying out audit testing, evaluating the results of these tests, and reporting on audit findings". Whereas Deis and Groux (1992) in Alim et al. (2007) explain that the probability of finding a violation depends on the auditor's technical ability and the probability of reporting a violation depends on the auditor's independence.

Regulation of the Republic of Indonesia Supreme Audit Agency No. 01 of 2007 concerning the State Financial Auditing Standards stated in all matters relating to the work of the examination, the organization of examiners and examiners, must be free in the mental attitude and appearance of personal interference, external, and organizations that can affect its independence. So to improve the attitude of independence of public sector auditors, the position of public sector auditors, both personally and institutionally, must be free from influence and interference and separate from the government. An independent auditor can submit his report to all parties in a neutral manner.

Davis et al. (2006) said obedience pressure is a condition experienced by the auditor when faced with a dilemma that an order from the leader who has a higher power causes the individual to obey orders that are contrary to the values he believes. The influence of obedience pressure is usually experienced by novice auditors, because they usually tend to obey orders from superiors and agencies inspected even though these orders are incorrect and can even violate professional standards (Pektra and Kurnia, 2014). This of course will cause pressure on the auditor to comply with or not obey the will of superiors and agencies. Based on a number of statements, the pressure of obedience is the pressure obtained by the auditor coming from the supervisor or someone who has the authority and the auditor will take actions that deviate from professional standards.

The internal control system (SPI) is a process that is carried out to provide adequate confidence regarding the achievement of the reliability of financial statements, compliance with the law, and the effectiveness \& efficiency of operations (Mulyadi and Puradiredja, 1998). American Institute of Certified Public Accountants (AICPA), 1947 as quoted by Wilopo (2006) explains that internal control is very important, among others, to provide protection for the entity against human weaknesses and to reduce the possibility of errors and actions that are not in accordance with the rules. Therefore, with the application and compliance of SPI by all layers, the audit report that will be produced by the auditor will be of higher quality. 
The success of SPI is very much dependent not only on the design of adequate controls to ensure the achievement of organizational goals, but also on everyone in the organization, as a factor that can make these controls function. To ensure the achievement of the objectives of the organization, based on PP No. 60 of 2008 has specified elements in the SPI which in its application must pay attention to a sense of fairness and compliance and take into account the size, complexity, and nature of the tasks and functions of Government Agencies which include the control environment, risk assessment, control activities, information \& communication, and monitoring /monitoring.

Robbins et al (2013) defines commitment as a condition in which an individual sits with the organization and its goals and desires to maintain its membership in the organization. Mathis and Jackson in Sopiah (2008) define organizational commitment as the degree to which employees believe and are willing to accept organizational goals and will remain or will not leave the organization. Furthermore, according to Aranya et.al in Prasetyono and Kompyurini (2007) defines commitment as k eyakinan and acceptance of goals and values of the organization; effort to strive or work for the benefit of the organization ; and the desire to maintain organizational membership.

Greenberg and Baron (2003: 160) defines organizational commitment is the degree to which employees are involved in their organization and wish to remain members, which contains an attitude of loyalty and willingness of employees to work optimally for the organization where the employee works. Argyris in Sukarno and Prasetyohadi (2004) divides commitment into two, namely internal commitment and external commitment. Internal commitment is a commitment that comes from the employee to complete various tasks, responsibilities and authority based on the reasons and motivations. External commitments are formed by the work environment, which arises because there are demands for the completion of tasks and responsibilities that must be completed by employees. The Heart and Minds approach (Armstrong, 1999) is an attempt to explain the secrets of business success that the best way to motivate people to achieve full commitment to organizational values is through leadership and involvement.

There are three dimensions of one's organizational commitment, namely (Allen and Meyer, 2013 ):

Affective commitment

This commitment refers to the emotional connection of members to the organization. People want to continue working for the organization because they agree with the goals and values in the organization. People with a high level of affective commitment have a desire to remain in the organization because they support the goals of the organization and are willing to help to achieve these goals.

Continuance commitment

This commitment refers to the desire of employees to remain in the organization because of the calculation or analysis of profit and loss where the perceived economic value of surviving in an organization is compared to leaving the organization. The longer employees stay with their organization, the more they are afraid of losing what they have invested in the organization so far.

Normative commitment (Normative commitment) 
This commitment refers to the feelings of employees where they are required to remain in the organization due to pressure from others. Employees who have a high level of normative commitment will pay close attention to what others say about them if they leave the organization. They don't want to disappoint their superiors and worry if their coworkers think badly of them because of the resignation. So organizational commitment is the attitude or form of a person's behavior towards the organization in the form of loyalty and the achievement of the organization's vision, mission, values and goals. Someone said to have a high commitment to the organization, can be recognized by the characteristics including trust and strong acceptance of the goals and values of the organization, a strong willingness to work for the organization and a strong desire to remain a member of the organization.

The research hypotheses proposed are as follows:

1. Competency affects the quality of audit results

2. Independence influences the quality of audit results

3. Compliance pressure affects the quality of audit results

4. The Internal Control System influences the quality of audit results

5. Organizational commitment influences the quality of audit results

\section{Research Method}

The quality of audit results is the quality of the auditor's work as indicated by a reliable audit report based on established standards. With indicators : 1) objective, 2) recomendation and 3 ) transparent

Competence is a qualification needed by the auditor to carry out an audit correctly

Independence is the independence of the auditor's position both in attitude and appearance in relation to other parties related to the audit work performed

Compliance pressure is a condition experienced by the auditor when faced with a dilemma that an order from the leader who has a higher power causes the individual to obey orders that are contrary to the values he believes.

The internal control system is a process that is carried out to provide adequate confidence regarding the achievement of the reliability of financial statements, compliance with laws, and effectiveness \& efficiency of operations

Organizational commitment is the attitude or form of a person's behavior towards the organization in the form of loyalty and the achievement of the organization's vision, mission, values and goals. With indicators : 1) proud to work at this agency, 2) agencies provide opportunities to improve performance, 3) loyal and will not leave this agency , 4) has become an option at this agency.

The subjects of this study were all government internal auditors . The target sample of this study is the number of variables ( 4 variables) multiplied by the number of observations / indicator variables (20 indicators), namely 4 x $30=120$ auditors (Hair, 2006). So the number of samples of this study was 120 auditors. This study uses a proportional random sampling technique to determine samples from auditors at each level of government auditors. Data collection techniques in this study is the use questionnaire to make a list of questions written on the items of the indicator variables of the study to get a goal to be achieved. Questions in 
this research questionnaire have been developed and adjusted by researchers from previous studies . Distributing the questionnaire was submitted in person or via email.

The data analysis technique in this study is to analyze data and test hypotheses using descriptive statistics, test hypotheses using regression analysis for warpPLS 6.0 software assistance. 1). Descriptive Analysis Descriptive statistics provide a description or description of each research variable as seen from the average (mean), standard deviation, maximum, minimum. Descriptive statistics were performed for me mpermudah view information data. Hypothesis testing uses the SEM (Structural Equation Modeling) analysis method with the aim of predicting and explaining constructs or latent variables. 2). Hypothesis Testing Hypothesis testing uses Partial Least Square (PLS) with the help of warpPLS software. PLS is a powerful analysis method because it is not based on many assumptions. PLS because PLS method has its own advantages including: the data do not have to be multivariate normal distribution (indicators with a scale category, ordinal, interval to ratio can be used on the same model) and the sample size does not have to be large. Although PLS is used to confirm the theory, it can also be used to explain the presence or absence of relationships between latent variables. PLS can analyze as well as constructs formed with reflexive indicators and formative indicators and this is not possible in the Structural Equation Model (SEM).

There are two stages in conducting SEM-PLS, but the two stages are carried out in a series, namely by confirming the measurement model that aims to evaluate the quality of data, namely the validity and reliability of data from latent or manifest variables and evaluation of goodness of fit.Then evaluating this model will be done structural design model (Inner Model) and measurement model (outer model). After the design of the model is carried out the next stage will be obtained the results of the level of significance as a basis for taking criteria for acceptance and rejection of hypothesis testing. The decision to accept the hypothesis for testing the effect directly on this study using the $\mathrm{p}$ value as a criterion for acceptance and rejection of hypotheses s. This study sets a significance value of 0.05 so that decisions are accepted if the value of $p<0.05$ and rejected if the value of $p>0.05$.

\section{Result and Discussion}

Based on the survey method in collecting data, 120 questionnaires were distributed and the percentage of respondents who returned and could be processed returned was 109. Based on 109 questionnaires distributed and all data processed, consisting of 49 male respondents (45\%) and 60 female respondents $(55 \%)$. The average level of education of respondents showed at the level of Strata One (S1) as many as 38 people (35\%) and strata two (S2) as many as 70 people $(65 \%)$ ie respondents who came from junior auditors were $39 \%$ with age an average of less than 35 years with tenure less than 10 years and $61 \%$ comes from senior auditors with an average age of more than 35 years with tenure of more than 10 years as the government internal auditor.

Based on data that can be processed from the answers of 109 respondents. All indicators used in the research model are valid with factor loading values above 0.50 and reliability values above 0.60 . This research model aims to empirically examine the effect of independence, strict pressure and organizational commitment on the quality of audit results . In detail, the results of the WarpPLS test can be seen in Table 1 and Table 2. Table 1 shows the resulting loading value is more than 0.50 and the resulting significant level is less 
than 5\%, except for the indicators Competency and Independence variables (K.5 and I.5) show $p>0.005$. Then it is re-tested (the second iteration) by eliminating indicators of Competency and Independence variables. Table 2 shows the resulting loading value is more than 0.50 and the resulting significant level is less than 5\%, then all indicators in this study are significantly valid.

Constructive reliability (composite reliability) can be seen in Table 3. Table 3 shows the results of the reliability test showed that the variables of competence, independence, obedience pressure, internal control systems, organizational commitment and the quality of the audit results are reliable, seen from the resulting composite reliability values above 0.70 , while seen from the value of Cronbach's alpha $<0,60$ According to Adbillah and Jogiyanto (2015: 207) states that composite reliability is a static technique for the same reliability test as Cronbach's alpha. However, composite reliability measures the true reliability value of one variable while Cronbach's alpha measures the lowest value of a variable's reliability so that the composite reliability value is always higher than the Cronbach's alpha value. According to Werts et al. (1974) in Salisbury et al. (2002), composite reliability is better used in PLS techniques. Average variance extracted (AVE) can be seen in Table 4 AVE (Average Variances Extracted). Table 4 shows the results of the reliability test shows that the variable pressure obedience and the quality of the audit results have a high discriminant validity, seen from the AVE value generated above 0.50. Hypothesis test can be seen in Table 5 that the AVIF value of $1,393<3.3$. and AFVIF value of $1,423<3.3$. So the research hypothesis was accepted. Summary of Model Testing can be seen in Table 6. This study sets a significance value of 0.05 so that decisions are accepted if the value of $p<0.05$ and rejected if the value of $p>0.05$. Table 6 shows that the first, second and fifth hypotheses of the supported study are indicated by $p<0.01$. This means that organizational competence, independence and commitment have an influence on the quality of audit results. Whereas adherence pressure and internal control systems do not affect the quality of audit results.

Competency affect the quality of the audit results. This means that the Government Internal Audit or better known as the Government Internal auditor Apparatus (APIP) in carrying out its work that is investigating and assessing internal control and the efficiency of the implementation of the functions of various organizational units to assist government management in controlling the activities of the work units they lead (quality assurance function) and consider the risk of fraud that significantly influences the audit objectives. APIP's contribution can provide input to the leadership of government administrators regarding the results, obstacles, and deviations that occur in the course of governance and development which are the responsibility of the leadership of the government administrators.

Independence affect the quality of the audit results. This means that APIP has been able to maintain its independence in carrying out its professional assignments where the independence of the auditor is absolutely necessary because the auditor is often referred to as the first party and plays a major role in conducting performance audits, because the auditor can access financial and management information from the organization being audited, has professional ability and are independent. In reality this independent principle is difficult to be truly implemented absolutely, between the auditor and the auditee must strive to maintain such independence so that the audit objectives can be achieved. APIP is able to consider carefully because the occurrence of non-compliance (abuse) is subjective. The APIP Chairperson is 
responsible to the highest leadership of the organization so that the responsibility for conducting the audit can be fulfilled. The APIP position is placed properly so that it is free from intervention, and receives adequate support from the highest leadership of the organization so that it can work together with the audi tee and carry out the work freely. Nevertheless, APIP must foster a good working relationship with audit ee especially in mutual understanding between the roles of each institution.

Obedience pressure does not affect the quality of audit results. This means that auditors often face work pressure, both superiors and client pressure. Auditors in carrying out their audits must obey and adhere to professional standards. Often the conflict that led to the emergence suasan dilemma for auditors whereby when the auditor was trying to be profesion a 1 and independence but on the one hand the auditors are required to follow the orders of superiors or audited entity. There are other pressures that are often faced by auditors in addition to obedience pressure, namely time budget pressure. However, this pressure can not make the auditor take actions that violate the inspection standards that will affect the results of the audit he did.

The Internal Control System does not affect the quality of audit results. This means that the government's internal auditors in carrying out their duties which consist of auditing, review, evaluation, monitoring and other supervision activities have not been carried out optimally. Supervision functions to help so that the goals set by the organization can be achieved, in addition to auditor functions to detect early deviations in implementation, abuse of authority, waste and leakage.

Organizational commitment influences the quality of audit results. This means that organizational commitment owned by a government internal auditor (APIP) is an attitude or form of behavior of a person towards the organization in the form of loyalty and achievement of the organization's vision, mission, values and goals. An APIP is said to have a high commitment to the organization, can be recognized by the characteristics including trust and strong acceptance of the goals and values of the organization, a strong willingness to work for the organization and a strong desire to remain a member of the organization. APIP also wants a supervisory apparatus that is clean, authoritative, orderly and orderly in carrying out its duties and functions in accordance with applicable provisions and norms. Norms and conditions applicable to government internal auditors consist of the APIP Code of Ethics and the APIP Audit Standards. The code of ethics is intended to maintain APIP's behavior in carrying out its duties, while the Audit Standards are intended to maintain the quality of the results of audits conducted by APIP. With the existence of these rules, the public or report users can assess the extent to which government auditors have worked in accordance with established standards and ethics. High organizational commitment is needed in an organization, because the creation of high commitment will affect professional work situations. Organizational commitment is related to the attitude of a person who is associated with the organization where they join. This attitude is related to the perception of organizational goals and involvement in carrying out work. If someone's commitment is high then the performance will be better.

Based on the results of research and discussion conducted, it can be concluded that :

1. Competency affects the quality of audit results. This means that the government's internal auditors are responsible for ensuring that each audit carried out already has the 
knowledge, expertise and experience needed to carry out their duties in order to produce quality audit results.

2. Independence influences the quality of audit results. This means that the government's internal auditors are able to maintain their independence in carrying out their professional assignments, where the independence of the auditor is absolutely necessary, because the auditor is often referred to as the first party and plays a major role in conducting performance audits, the auditor can access financial and management information from the organization that audited, and has professional ability and is independent

3. Obedience pressure does not affect the quality of audit results. This means that the government internal auditors still often encounter obstacles in its implementation where there is a sense of kinship, togetherness and prominent human considerations. The usual pressure on the government environment is more focused on obedience pressure, because government auditors work on orders (superiors) for and on behalf of the internal auditor as an institution under control or authorization which will ultimately lead to reduced audit quality

4. The Internal Control System does not affect the quality of audit results. This means that the government internal auditors in carrying out their duties consisting of auditing, review, evaluation, monitoring and other supervisory activities are not optimal.

5. Organizational commitment influences the quality of audit results. This means that organizational commitment possessed by a government internal auditor (APIP) is an attitude or form of a person's behavior towards the organization in the form of loyalty and achievement of the organization's vision, mission, values and goals. High organizational commitment is needed in an organization, because the creation of high commitment will affect professional work situations. Organizational commitment is related to the attitude of a person who is associated with the organization where they join. This attitude is related to the perception of organizational goals and involvement in carrying out work. If someone's commitment is high then the performance will be better.

\section{Acknowledgement}

I would like to express my very great appreciation to all the authors

\section{References}

Allen and Meyer. The Measurement and Antecedents of Affective, Contingency and Normative Commitment to Organitazion. PT Elex Media Komputindo, Jakarta. (2013).

Allen, NJ, and Meyer, JP. A Three Component Conceptualization of Organizational Commitment, Human Resource Management Review, Volume 1, Number 1. (1991).

Allen, NJ, and Meyer, JP . The measurement and antecedents of affective, continuance, and normative commitment to organizations. Journal of occupational psychology. (1990). 
Alvin A. Arens, Randal J. Elder, and Mark S. Beasley. Audit and Assurance Services: Integrated Approaches (Indonesian Adaptation), Pearson Education International, Salemba Empat. (2008).

Arens, AA, and JK Loebbecke, Auditing: An Integrated Approach." Eight Edition. (2011)

Arifah, Agency Theory Practices in Public and Non-Public Entities. Achievements Vol. 9 No.1 June 2012 ISSN 1411-1497. (2012).

Financial and Development Supervisory Agency (BPKP). Regulation of the Head of the Financial and Development Supervisory Agency (BPKP) No: PER-211 / K / JF / 2010 concerning Auditor Competency Standards. (2010).

Bowrin, Anthony R and James King II. Time Pressure, Task Complexity, and Audit Effectiveness. Managerial Auditing Journal, 25 (2), pp: 160-181. (2010).

Choo, Freddie, and Ken T. Trotman. The Relationship Between Knowledge Structure and Judgment for Experienced and Experienced Auditors. The Accounting Review (July), pp.464-485. (1991).

Christiawan, YJ. Competence and Independence of Public Accountants: Reflections on Empirical Research Results, Journal of Accounting and Finance, Vol. 4, No. 2, November 2002, pp. 79-92. (2002).

Deis, Donald L. And Gari A. Giroux. Determinants of Quality Audit in the Public Sector. The Accounting Review Vol. 67 No. 3 (July). Pp. 462-479. (1992).

Donald R. Cooper, Pamela S. Schindler. Business Research Methods, Boston, McGrawHill. (2011).

Faizah R and Zuhdi. Factors That Influence the Quality of Examination (Study of BPK Representative in East Java). JAFFA Vol. 01 No. 2 October 2013 Pg. 83-98. (2013).

GAO. Government Auditing Standards" Washington, Government Publishing Office Greenberg, J. \& Baron, RA (2003) Behavior in Organizations Understanding and Managing the Human Side of Work. New Jersey: Prentice-Hall International. (2011).

Jensen, Michael C and William H. Meckling. Theory of Firm: Managerial Behavior, Agency Cost and Ownership Sructure. Journal of Financial Economics 3 (1976) 305-360. North-Holland Publish Company. (1976).

Harry Suharto. Local Government Audit Compliance. Media Accounting. Issue 26. May June. pp. 14-15. (2002) .

IAPI Professional Standards for Public Accountants. Jakarta. Salemba Empat. (2018).

Ida Rosnidah. Audit Quality, Concept and Implementation in Indonesia. Cirebon: Swagati Press. (2010) .

Indra, Bastian. Public Sector Accounting. Jakarta: Erlangga. (2006) 
K. Bertens. Ethics, Jakarta, Gramedia Main Library. (2000).

Knechel, Krishnan, Pevzner, Shefchik and Velury. Auditing A Journal of Practice \& Theory32 (Supplement 1). (2012)

King, James, Robert Welker and Gary Keller. "The Effect of Independence Allegation on Peer Review Evaluation of Audit Procedures". Behavioral Research in Accounting Vol. 6 (1994).

Knapp, Michael C. Audit Conflict: an Empirical Study of the Perceived Ability of Auditors to Resists Management Pressure". The accounting Review (April), pp.202-211. (1985).

Kusharyanti. Research Findings Regarding Audit Quality and Future Research Topics, Journal of Accounting and Management, Vol 2, No. 2, 2003 pp. 25-34. (2003).

Lee, Hua. Incentive Contracts and Time Pressure on Quality Audit Quality Judgment Performance. Managerial Auditing Journal. 27 (3), pp: 263-283. (2012).

Lowensohn, et. al. Auditor Specialization and Perceived Quality Audit, Auditee Satisfaction and Audit Fees in the Local Government Audit Market. (2005).

Mermod, Yuskel Asli, Sungun, Gokhan. Internal audit positioning four stage model. Journal of business economics \& finance, 2 (1), pp: 2146-7493. (2013).

Mohamed, Diana Mostafa and Magda Hussien Habib. Auditor independence, Quality Audit and The Mandatory Auditor Rotation In Egypt. Education Business and society, 6 (2), pp: 116-144. (2013).

Mangkunegara, AP. Evaluation of Human Resources Performance. First Matter.Bandung: PT. Rafika Aditama. (2005).

Mardiasmo. Public sector accounting. Yogyakarta: Andi Publisher. (2011).

Mayangsari, Sekar. The effect of expertise and independence on audit opinion: A quasiexperiment. Indonesian Accounting Research Journal Vol.6 No.1 (January) (2003).

Meutia, Intan. The auditor's independence of Profit Management for the Big 5 and non Big 5 hoods. Indonesian Journal of Accounting Research Vol. 2 No. 1 (January). Pp37-52. (2004).

Muindro Renyowijoyo. Public Perceptions and Accountants towards the Professional Ethics of Accountants. Journal of Business and Accounting. Vol. 7 No. 1. April 2005 pp 66-83. (2005).

Mulyadi. Auditing. Book 1, Issue 6. Jakarta: Salemba Empat. (2014).

Muslim et al., Effects of Auditor Competence, Compliance Pressure, and Task Complexity on Audit Judgments. Bongaya Journal for Research in Accounting Volume 1 Number 2 October 2018. Pages 08-17. e-ISSN: 2615-8868 Homepage: https://ojs.stiembongaya.ac.id/index.php/BJRA (2018). 
Partono. Government Financial Reports: Efforts towards Transparency and Accountability. Media Accounting. 14. October edition. pp. 25-26. (2000).

Regulation of the Supreme Audit Board of the Republic of Indonesia Number 01 of 2007. State Financial Audit Standards. Jakarta. (2007).

Regulation of the Minister of State for Administrative Reform Number PER / 05 / M.PAN / 03.2008. Government Internal Audit Apparatus Auditing Standards. Jakarta. (2008).

Prajogo. Auditor's Perspective on the Implementation of Public Sector Financial Accounting Standards. Journal of Public Sector Accounting and Finance. Public Sector Accountant Compartment Indonesian Institute of Accountants. Vol. 02 No. 02. August. pp. 1 - 8. (2001)

Robbins SP, and Judge. Organizational Behavior, Salemba Empat, Jakarta. (2013).

Rose, Richard (et al.). Setting Standards for Good and Bad Governance. Palgrave Macmillan (2019).

Safitri. The influence of Auditor independence and Leadership Style on Auditor Performance with Organizational Commitment as an Intervening variable. Scientific Journal of Economics and Business Vol. 11, No. 2, September 2014: 339 - 351 ISSN: 1829 - 9822. (2014).

Salsabila, Ainia, Hepi Prayudiawan. The Effect of Accountability, Audit Knowledge and Gender on the Quality of the Work of Internal Auditors. Journal of Accounting Research \& Research. Vol. 4. No. July 1, 2011. Pg. 155-175. (2011).

Sapariyah, Rina Ani. The Effect of Good Governance and Auditor Independence on Auditor Performance and Organizational Commitment (Survey on Public Accounting Firms in Surakata). Journal of Business and Banking Economics, May, Vol. 19, No. 16. (2011) .

Slamet Sugiri and Nasuhi Hidayat, Auditors and Users' Perception of Audit Reports and Review Reports. Journal of Business and Accounting. Vol. 5, No. 3. December 2005 pp. 301-321. (2003).

Sopiah Organizational Behavior. Yogyakarta. (2008).

Sukarno, Fatso. Prasetyohadi. Analysis of the Effect of Job Satisfaction and Organizational Commitment on Employee Morale." Scientific Journal of Accounting. (2004).

Sukrisno Agoes and I Cenik Ardana. Business and professional ethics. Jakarta: Salemba Empat. (2009).

Suryanita Weningtyas, et al., Termination of Premature Audit Procedures. Indonesian Accounting Research Journal. Vol.10, No.1. January 2007 p. 1-9. (2007). 
Tsui, Judi SL and Ferdinand A. Gul. Auditors Behavior in an audit. Conflict Situation: A Research Note on the Role of Locus of Control and Ethical Reasoning. Acoounting Organization and Society vol.21, No.1, pp.41-51. (1996).

Uma, Sekaran. Reaseach Methods For Business. Book 1. Issue 4, First Edition.. Jakarta: Salemba Empat. (2006)

Watkins, Ann. L, William Hillison and Susan E. morecroft. Audit Quality: A Synthesis of Theory and Empirical Evidence. Journal of Accoounting Literature Vol.23. Pp. 153-193. (2004).

Wibowo. Performance Management. Jakarta.PT. Rajagrafindo Persada. (2010) .

Wilopo. Analysis of Factors that Influence the Tendency of Accounting Fraud: A Study of Public Companies and State-Owned Enterprises in Indonesia. Journal of Accounting Research. Vol. 9, No. 3. September 2006 Pages 346-366. (2006).

Wilopo. Factors that Determine Audit Quality in the Public/Government Sector". Ventura Perbanas Surabaya STIE. Vol. 4 No. 1. June. pp. 27 - 32. (2001).

Http :// www.publika.com/2009/11/laporan-hasil-pemeriksaan-BPK-RI-TA.html.

http :// www.publika.com/2009/11/laporan-hasil-pemeriksaan-BPK-RI-TA.html.

http://fe.unira.ac.id/wp-content/uploads/2012/11/Makalah-II.pdf

\section{NOTES:}

Tables. 
1 Indicator of Validity ( Outer Loading )

Table 1

Value of Loading ( Outer Loading )

Nilai Loading (Outer Loading)

\begin{tabular}{|c|c|c|c|c|c|c|c|c|c|}
\hline \multicolumn{10}{|c|}{$\begin{array}{l}* * * * * * * * * * * * * * * * * * * * * * * * * * * * * * * * * * * * \\
* \text { Combined loadings and cross-loadings } *\end{array}$} \\
\hline \multicolumn{10}{|c|}{ *******************************************1} \\
\hline & compt & Indpdc & $\mathrm{OP}$ & Intlctr & $\mathrm{OC}$ & AQR & Type (a & SE & $\mathrm{P}$ value \\
\hline C. 1 & 0.888 & -0.098 & -0.048 & 0.012 & 0.028 & -0.103 & Reflect & 0.076 & $<0.001$ \\
\hline C. 2 & 0.895 & -0.105 & -0.074 & -0.039 & 0.096 & -0.132 & Reflect & 0.076 & $<0.001$ \\
\hline C. 3 & 0.494 & 0.225 & 0.211 & -0.040 & -0.341 & 0.344 & Reflect & 0.085 & $<0.001$ \\
\hline C. 4 & 0.646 & 0.206 & -0.003 & 0.095 & 0.056 & 0.067 & Reflect & 0.081 & $<0.001$ \\
\hline C. 5 & -0.080 & 0.797 & -0.092 & 0.228 & -0.269 & 0.049 & Reflect & 0.094 & 0.200 \\
\hline I.1 & -0.042 & 0.778 & 0.107 & 0.167 & -0.231 & 0.055 & Reflect & 0.079 & $<0.001$ \\
\hline I. 2 & 0.126 & 0.899 & -0.053 & -0.014 & -0.106 & -0.055 & Reflect & 0.076 & $<0.001$ \\
\hline I. 3 & -0.181 & 0.906 & -0.069 & -0.011 & 0.189 & -0.030 & Reflect & 0.076 & $<0.001$ \\
\hline I. 4 & 0.182 & 0.514 & 0.077 & -0.234 & 0.236 & 0.067 & Reflect & 0.084 & $<0.001$ \\
\hline I. 5 & 0.246 & -0.043 & 0.302 & -0.316 & 0.405 & 0.009 & Reflect & 0.095 & 0.326 \\
\hline OP.1 & 0.113 & -0.004 & 0.710 & 0.200 & -0.074 & 0.063 & Reflect & 0.080 & $<0.001$ \\
\hline OP. 2 & -0.040 & 0.149 & 0.873 & -0.078 & 0.153 & -0.133 & Reflect & 0.077 & $<0.001$ \\
\hline OP.3 & 0.038 & 0.105 & 0.866 & 0.066 & -0.180 & -0.061 & Reflect & 0.077 & $<0.001$ \\
\hline OP.4 & -0.019 & -0.227 & 0.802 & -0.275 & 0.141 & 0.080 & Reflect & 0.078 & $<0.001$ \\
\hline OP. 5 & -0.214 & -0.123 & 0.294 & 0.304 & -0.130 & 0.204 & Reflect & 0.089 & $<0.001$ \\
\hline
\end{tabular}


Source: Data processed

Source: Data processed (2019)

Table 2

Value of Loading ( Outer Loading )

\begin{tabular}{|c|c|c|c|c|c|c|c|c|c|}
\hline & compt & Indpdc & OP & Intlctr & OC & AQR & Type (a & SE & $P$ value \\
\hline C. 1 & 0.888 & -0.098 & -0.048 & 0.012 & 0.028 & -0.103 & Reflect & 0.076 & $<0.001$ \\
\hline C. 2 & 0.895 & -0.105 & -0.074 & -0.039 & 0.096 & -0.132 & Reflect & 0.076 & $<0.001$ \\
\hline C. 3 & 0.494 & 0.225 & 0.211 & -0.040 & -0.341 & 0.344 & Reflect & 0.085 & $<0.001$ \\
\hline C. 4 & 0.646 & 0.206 & -0.003 & 0.095 & 0.056 & 0.067 & Reflect & 0.081 & $<0.001$ \\
\hline I. 1 & -0.042 & 0.778 & 0.107 & 0.167 & -0.231 & 0.055 & Reflect & 0.079 & $<0.001$ \\
\hline I. 2 & 0.126 & 0.899 & -0.053 & -0.014 & -0.106 & -0.055 & Reflect & 0.076 & $<0.001$ \\
\hline I. 3 & -0.181 & 0.906 & -0.069 & -0.011 & 0.189 & -0.030 & Reflect & 0.076 & $<0.001$ \\
\hline I. 4 & 0.182 & 0.514 & 0.077 & -0.234 & 0.236 & 0.067 & Reflect & 0.084 & $<0.001$ \\
\hline OP.1 & 0.113 & -0.004 & 0.710 & 0.200 & -0.074 & 0.063 & Reflect & 0.080 & $<0.001$ \\
\hline OP.2 & -0.040 & 0.149 & 0.873 & -0.078 & 0.153 & -0.133 & Reflect & 0.077 & $<0.001$ \\
\hline OP.3 & 0.038 & 0.105 & 0.866 & 0.066 & -0.180 & -0.061 & Reflect & 0.077 & $<0.001$ \\
\hline OP.4 & -0.019 & -0.227 & 0.802 & -0.275 & 0.141 & 0.080 & Reflect & 0.078 & $<0.001$ \\
\hline OP.5 & -0.214 & -0.123 & 0.294 & 0.304 & -0.130 & 0.204 & Reflect & 0.089 & $<0.001$ \\
\hline ICS. 1 & -0.001 & -0.063 & -0.028 & 0.810 & -0.211 & 0.086 & Reflect & 0.078 & $<0.001$ \\
\hline ICS. 2 & 0.070 & 0.050 & -0.080 & 0.828 & -0.240 & 0.028 & Reflect & 0.077 & $<0.001$ \\
\hline ICS. 3 & -0.023 & 0.141 & -0.022 & 0.882 & -0.041 & 0.038 & Reflect & 0.076 & $<0.001$ \\
\hline ICS. 4 & 0.077 & -0.023 & 0.098 & 0.801 & 0.048 & -0.002 & Reflect & 0.078 & $<0.001$ \\
\hline ICS.5 & -0.141 & -0.139 & 0.043 & 0.695 & 0.528 & -0.180 & Reflect & 0.080 & $<0.001$ \\
\hline OC.1_ & -0.032 & -0.007 & -0.159 & 0.293 & 0.656 & -0.198 & Reflect & 0.081 & $<0.001$ \\
\hline OC. $2^{-}$ & 0.073 & 0.082 & 0.022 & 0.014 & 0.885 & 0.026 & Reflect & 0.076 & $<0.001$ \\
\hline OC. 3 & 0.021 & -0.180 & -0.029 & 0.060 & 0.643 & 0.023 & Reflect & 0.081 & $<0.001$ \\
\hline OC.4 & 0.039 & -0.093 & 0.024 & -0.100 & 0.842 & 0.038 & Reflect & 0.077 & $<0.001$ \\
\hline OC. 5 & -0.188 & 0.263 & 0.173 & -0.332 & 0.478 & 0.126 & Reflect & 0.085 & $<0.001$ \\
\hline AQR.1 & -0.001 & 0.032 & 0.302 & -0.456 & 0.445 & 0.550 & Reflect & 0.083 & $<0.001$ \\
\hline AQR.2 & -0.222 & -0.108 & 0.221 & -0.601 & 0.527 & 0.387 & Reflect & 0.087 & $<0.001$ \\
\hline AQR.3 & -0.048 & -0.163 & -0.068 & 0.069 & -0.058 & 0.724 & Reflect & 0.080 & $<0.001$ \\
\hline AQR.4 & -0.016 & -0.083 & -0.259 & 0.142 & -0.026 & 0.816 & Reflect & 0.078 & $<0.001$ \\
\hline AQR.5 & 0.067 & 0.079 & -0.129 & 0.196 & -0.191 & 0.837 & Reflect & 0.077 & $<0.001$ \\
\hline AQR.6 & 0.099 & 0.182 & 0.147 & 0.195 & -0.285 & 0.793 & Reflect & 0.078 & $<0.001$ \\
\hline
\end{tabular}


Source: Data processed (2019)

Table 3

Reliability test with Composite reliability coefficients and Cronbach's alpha coefficients

\begin{tabular}{|c|c|c|c|c|c|}
\hline \multicolumn{6}{|c|}{ Composite reliability coefficients } \\
\hline Compt & Indpdc & OP & Intlctr & OC & $\mathrm{AQR}$ \\
\hline 0.746 & 0.789 & 0.848 & 0.902 & 0.834 & 0.848 \\
\hline
\end{tabular}

Source: Data processed (2019)

Table 4

AVE (Average Variances Extracted)

Average variances extracted

Source: Data processed (2019) 
Table 5

\section{VIF test}

\begin{tabular}{|c|c|c|c|c|c|}
\hline Full ce & nearity & & & & \\
\hline compt & Indpdc & OP & Intlctr & $\mathrm{OC}$ & AQR \\
\hline
\end{tabular}

Source: Data processed

Table 5 shows that the AVIF value of $1,393<3.3$. and AFVIF value of $1,423<3.3$. So the research hypothesis was accepted.

Table 6 Summary of Model Testing

\begin{tabular}{|c|c|c|}
\hline Model & $\mathrm{P}$ & Conclusion \\
\hline Competence in the quality of audit results (H1) & $\mathrm{P}=0.04$ & H1 : supported \\
\hline Independence of audit results quality (H2) & $\mathrm{P}<0.01$ & H 2 : supported \\
\hline Pressure adherence to the quality of audit results $(\mathrm{H} 3)$ & $\mathrm{P}=0.08$ & H 3 : Rejected \\
\hline Internal control system on the quality of audit results (H4) & $\mathrm{P}=0.34$ & H 4 : Rejected \\
\hline $\begin{array}{l}\text { Organizational commitment influences the quality of audit } \\
\text { results (H5) }\end{array}$ & $\mathrm{P}<0.01$ & H 5 : supported \\
\hline
\end{tabular}

Source: Data processed 